\title{
Engineering Design: \\ Using a Scoring Rubric to Compare the Products \\ Of Teams that Differ in Gender Composition
}

\author{
Barbara M. Moskal, Robert Knecht, Debra Lasich \\ Colorado School of Mines
}

\begin{abstract}
This study uses an analytic scoring rubric to evaluate the quality of the final reports that are produced by students in engineering design teams. The student teams consisted of four to six members and varied in their gender composition. Based on the results of this study, gender composition appears to have had an impact on the quality of the team submitted final reports. This paper will discuss the specific facets of the reports that varied by gender composition.
\end{abstract}

\section{Introduction}

The importance of retaining and advancing women in engineering has been supported by several arguments. The first argument relies upon the concepts of fairness and equity. By not participating in engineering, women are barred from the economic rewards of this field ${ }^{1-3}$. More recent arguments recognize that not only is female participation advantageous to the individual but also to the advancement of a given field. Women make contributions to fields that are unique from that of the majority population ${ }^{3-8}$. Engineering design is an essential activity within the field of engineering. In order to retain more women within this field, a better understanding is needed of the female experience during the engineering design team process.

Recognizing this need, the National Science Foundation's Activities for Women and Girls in Science, Engineering \& Mathematics program has sponsored the Engineering Design Teams: Influence of Gender Composition on the Decision-Making Process project (EHR-9979444) at the Colorado School of Mines (CSM). This project seeks to better understand the interactions that take place between men and women during the team decision making process in the Design Engineering Practices Introductory Course Sequence (EPICS). Design EPICS is a sequence of required first and second year courses at CSM in engineering design. As the first courses that students take in engineering design, EPICS has the potential of either encouraging or discouraging students' (particularly females) interests in engineering.

An earlier report concerning this project found that male and female leaders in engineering design teams displayed few behavioral differences during the team process ${ }^{9}$. Yet, team members' descriptions of the leadership qualities of their male and female leaders were very different. The female leader was described as "being the only female" and therefore, was permitted by the males to take the leadership role. The male leader, on the other hand, was described as having long-range goals, organizational skills, computer skills, an ability to get things done, and an ability to take charge. In other words, engineering design team members 
described their male and female leaders differently, even when observations suggested that there were few differences between the leaders' actual behaviors.

Another report ${ }^{10}$ found that the gender of a given team member had little impact upon the behaviors that individual team members displayed. However, the gender composition of the overall team did have an impact on the behaviors that team members displayed. Members of male dominated teams were significantly more likely to be witnessed encouraging other team members to contribute to the team effort than were other team compositions. Members of male dominated teams were also significantly more likely than were members of female dominated or equally mixed teams to set standards for the team to reach by a designated time. In other words, the gender composition of the team appeared to be related to the behaviors that the team members displayed.

Another question that is of interest with respect to the engineering design team process is whether the gender composition of the team has an impact on the quality of the team's final product? Addressing this question is the focus of the current paper. Each of the student teams in the current investigation submitted a final written report that described their solution to an engineering design project. These final reports were analyzed in a standard manner using the design scoring rubric, an instrument that resulted from an extensive validation process ${ }^{11,12}$. Scoring rubrics are descriptive rating scales that are useful in the evaluation of students' performances that evolve over an extended period ${ }^{13}$. Over the course of a semester, EPICS students work in teams to solve problems and develop final reports based on these efforts. Since the final reports are a result of students' efforts over an extended period, scoring rubrics are an appropriate methodology for evaluating the outcome of the students' performances ${ }^{13,14}$.

\section{Research Questions}

The purpose of this paper is to examine the effectiveness of a scoring rubric for comparing the quality of engineering design final reports that were submitted by teams that differed by gender composition. The specific research questions that will be addressed are:

1. Does the overall quality of team produced final reports as measured by the scoring rubric differ when the teams have varying gender compositions?

2. What facets of the final reports as measured by the scoring rubric differ when the teams vary by gender composition?

III. Methods

\section{A. Course}

The EPICS sequence is a two-semester, six credit-hour course sequence that is required of all first and second-year students. This sequence is designed to provide students with a broad-based introduction to engineering design, technical communications and teamwork. A mentor works with teams of four to six students to solve authentic problems, similar to projects engineers 
would encounter at the workplace. All projects are authentic in that they are problems that have been solicited from the government, industry and businesses.

\section{B. Projects}

All of the freshman students completed the same project, Transporting Lunar Regolith. The purpose of this project was for the teams to develop ways to transport regolith, which is the layer of finely ground dirt on lunar surfaces, to be processed. The sophomore EPICS classes had 14 projects from which to select. Brief descriptions of several example projects are shown in Table 1. This table originally appeared in Laeser-MacDonell et al. ${ }^{10}$ and is reproduced here with permission.

Throughout the semester, the student teams worked to develop a solution to the proposed problem. At the end of the semester, these teams developed a written report that described their proposed solutions for a client. The "client" was defined to be the government sector, industry or business that had proposed the original project.

\begin{tabular}{ll}
\hline Title of Project & Description \\
\hline EPA Indoor Air Quality Extension & $\begin{array}{l}\text { Teams identify obstacles and offered suggestions to } \\
\text { improve the airflow in large buildings. }\end{array}$ \\
Planetary Rover Test Prototype & $\begin{array}{l}\text { Teams completed a design study on existing } \\
\text { mechanical vehicle that is suitable to use for } \\
\text { planetary regolith excavation and volatile extraction. }\end{array}$ \\
Playground Equipment & $\begin{array}{l}\text { Teams focused on installing playground equipment } \\
\text { that was designed to encourage children with } \\
\text { disabilities to interact with their peers. }\end{array}$ \\
Ethanol Marketing Study & $\begin{array}{l}\text { Teams investigated the market potential for an } \\
\text { ethanol product, specifically from cellulosic } \\
\text { biomass. }\end{array}$ \\
Potato Flower Mold Presentation & $\begin{array}{l}\text { The teams designed, developed and constructed a } \\
\text { food prototypical mold (something like a cupcake } \\
\text { pan) to bake several whipped potato flowers at a } \\
\text { time. }\end{array}$ \\
\hline
\end{tabular}

Table 1. Description of Second Year Design EPICS Projects

\section{Team Formations}

A "team" in this study is composed of two or more students and requires the coordination of all members' efforts to accomplish a goal ${ }^{15}$. Teams consisted of four to six members and were constructed in the following formations: 1) all males, 2) more males than females, 3) more females than males, and 4) half female and half male. Due to the small proportion of women as 
compared to men, the construction of all female teams was not possible. The teams in the first, second, third and fourth formation will be referred to as "all male", "male dominated", "female dominated" and "mixed", respectively, throughout the remainder of this document. How the teams were formed within a given classroom was left to the discretion of the instructor. In other words, in some classrooms the instructor assigned students to a team and in other classrooms the students selected their own team.

The unit of measurement in this investigation is the team. Within Design EPICS I, twenty-eight, twenty-three, five and eight teams were all male, male dominated, female dominated, and mixed, respectively. Within Design EPICS II, nine, sixteen, six and zero of the teams were all male, male dominated, female dominated, and mixed, respectively. This resulted in a total of thirtyseven, thirty-nine, eleven and eight teams that were all male, male dominated, female dominated, and mixed, respectively.

\section{Instrument}

As was discussed earlier, each of the student teams submitted a final report at the end of the semester. In order to evaluate the quality of the students' written final reports, the design scoring rubric (i.e., scoring scheme) was used ${ }^{11,12}$. The specific student outcomes that the rubric was designed to assess are:

1. The team's proficiency in understanding the requirements of an external client.

2. The team's proficiency in designing and justifying a feasible solution for a project.

3. The team's proficiency in collecting, examining and interpreting empirical evidence.

4. The team's proficiency to communicate in writing the technical and economical feasibility of an engineering strategy.

The analytic scoring rubric was designed to evaluate both technical content (objectives 1, 2 and 3 ) and the effectiveness of the written communication (objective 4) apparent in the final report. The content portion of this rubric, which is shown in Table 2, was reviewed and revised through the collaborative efforts of engineers and an assessment specialist and covers the areas of "audience", "purpose" and "evidence". The category of "audience" is designed to address objective 1: Whether the team identifies who the client is and what the client's needs are. This is considered an initial and essential step in industry when working with an external client. The second category, "purpose", examines the extent to which the teams develop and justify a feasible solution to the given problem (i.e., objective 2). The "evidence" category examines the appropriateness and effectiveness of the student presented empirical evidence for supporting the proposed solution (i.e., objective 3 ).

The communication portion of this rubric, which is shown in Table 3, was developed through the combined efforts of an English and a Communications expert and was reviewed by an assessment specialist. This portion emphasizes focus and coherence and assesses objective 4. 


\begin{tabular}{|c|c|c|c|c|}
\hline & $-0-$ & $\begin{array}{c}-1- \\
\text { Needs Improvement } \\
\text { "Data Dump" }\end{array}$ & $\begin{array}{c}\text {-2- } \\
\text { Adequate } \\
\text { "Partial Synthesis" }\end{array}$ & $\begin{array}{l}\text {-3- } \\
\text { Meets Expectations for a first Draf } \\
\text { of a Professional Report } \\
\text { "Synthesis of the Information" }\end{array}$ \\
\hline $\begin{array}{l}\text { Audience } \\
\text { (CLIENT) } \\
\text { Who is the client and } \\
\text { what are their needs? }\end{array}$ & $\begin{array}{l}\text { - Does not identify client } \\
\text { OR } \\
\text { - Clients' needs. }\end{array}$ & $\begin{array}{l}\text { - Specifies who the client is } \\
\text { OR } \\
\text { - Specifies what the client's } \\
\text { needs are. }\end{array}$ & $\begin{array}{l}\text { - Specifies who the client is, } \\
\text { what the client's needs are, } \\
\text { BUT } \\
\text { - Addresses only a subset of } \\
\text { the client's needs. }\end{array}$ & $\begin{array}{l}\text { Specifies who the client is, } \\
\text { what the clients' needs are, } \\
\text { AND } \\
\text { Clearly addresses all the } \\
\text { clients' needs. }\end{array}$ \\
\hline $\begin{array}{l}\text { Purpose } \\
\text { (CONCLUSION) } \\
\text { What is the problem and } \\
\text { how can it be solved? }\end{array}$ & $\begin{array}{l}\text { - The description of the } \\
\text { nature of the problem to be } \\
\text { solved } \\
\text { AND/OR } \\
\text { - The proposed solution is } \\
\text { missing. }\end{array}$ & $\begin{array}{l}\text { - The nature of the problem to } \\
\text { be solved AND the } \\
\text { proposed solution are } \\
\text { clearly expressed, } \\
\text { BUT } \\
\text { - Links between the two are } \\
\text { not explicit. }\end{array}$ & $\begin{array}{l}\text { - Clearly describes the nature } \\
\text { of the problem to be solved, } \\
\text { the proposed solution, } \\
\text { AND } \\
\text { - Provides some textual } \\
\text { and/or graphical evidence } \\
\text { that supports the proposed } \\
\text { solution. }\end{array}$ & $\begin{array}{l}\text { - Clearly describes the nature } \\
\text { of the problem to be solved, } \\
\text { the proposed solution, } \\
\text { AND } \\
\text { - Uses text and graphics to } \\
\text { provide a persuasive } \\
\text { argument to adopt the } \\
\text { proposed solution. }\end{array}$ \\
\hline $\begin{array}{l}\text { Why is the proposed } \\
\text { solution the 'best' } \\
\text { solution? }\end{array}$ & $\begin{array}{l}\text { Document is missing one or } \\
\text { more of the following: } \\
\text { 1. Alternative solutions, } \\
\text { 2. Major specifications, } \\
\text { AND } \\
\text { 3. Information pertinent to } \\
\text { the plan. }\end{array}$ & $\begin{array}{l}\text { Document identifies each of the } \\
\text { following: } \\
\text { 1. Alternative solutions, } \\
\text { 2. Major specifications, } \\
\text { AND } \\
\text { 3. Information pertinent to the } \\
\text { plan. }\end{array}$ & $\begin{array}{l}\text { Document shows some links } \\
\text { among the following: } \\
\text { 1. Alternative solutions, } \\
\text { 2. Major specifications, } \\
\text { AND } \\
\text { 3. Information pertinent to the } \\
\text { plan. }\end{array}$ & $\begin{array}{l}\text { Document provides persuasive } \\
\text { argument that links the } \\
\text { following: } \\
\text { 1. Alternative solutions, } \\
\text { 2. Major specifications, } \\
\text { AND } \\
\text { 3. Information pertinent to the } \\
\text { plan. }\end{array}$ \\
\hline
\end{tabular}

Table 2. Content Portion of Final Report Scoring Rubric 


\begin{tabular}{|c|c|c|c|c|}
\hline & -0 & $\begin{array}{c}-1- \\
\text { Needs Improvement }\end{array}$ & $\begin{array}{l}-2- \\
\text { Adequate }\end{array}$ & $\begin{array}{l}\stackrel{-3-}{\text { Meets Expectations for a first }} \\
\text { Draft of a Professional Report }\end{array}$ \\
\hline $\begin{array}{l}\text { Focus } \\
\text { (ORGANIZATION) } \\
\text { Is the organization of the } \\
\text { document effective? }\end{array}$ & $\begin{array}{l}\text { - There appears to be no } \\
\text { organization of the } \\
\text { document's contents. }\end{array}$ & $\begin{array}{l}\text { - Organization of document is } \\
\text { difficult to follow due to a } \\
\text { combination of the } \\
\text { following: } \\
\text { 1. Inadequate transition, } \\
\text { 2. Rambling format } \\
\text { 3. Insufficient or irrelevant } \\
\text { information } \\
\text { OR } \\
\text { 4. Ambiguous graphics }\end{array}$ & $\begin{array}{l}\text { - The document can be easily } \\
\text { followed. A combination of } \\
\text { the following are apparent } \\
\text { in the document: } \\
\text { 1. Basic transitions are used, } \\
\text { 2. A Structured format is used, } \\
\text { 3. Some supporting graphics } \\
\text { are provided. }\end{array}$ & $\begin{array}{l}\text { - The document can be easily } \\
\text { followed. A combination of } \\
\text { the following are apparent } \\
\text { in the document: } \\
\text { 1. Effective transitions are } \\
\text { used, } \\
\text { 2. A professional format is } \\
\text { used, } \\
\text { 3. The graphics are descriptive } \\
\text { and clearly support the } \\
\text { document's purpose. }\end{array}$ \\
\hline $\begin{array}{l}\text { Coherence } \\
\text { (CLARITY) } \\
\text { Are the sentences that } \\
\text { comprise the document } \\
\text { clear and effective? }\end{array}$ & $\begin{array}{l}\text { - Sentences are difficult to } \\
\text { read and understand. }\end{array}$ & $\begin{array}{l}\text { - The document contains } \\
\text { numerous distractions in } \\
\text { that appear in the a } \\
\text { combination of the } \\
\text { following forms: } \\
\text { 1. Flow in thought } \\
\text { 2. Graphical presentations } \\
\text { 3. Grammar/mechanics }\end{array}$ & $\begin{array}{l}\text { - The document contains } \\
\text { minimal distractions that } \\
\text { appear in a combination of } \\
\text { the following forms: } \\
\text { 1. Flow in thought } \\
\text { 2. Graphical presentations } \\
\text { 3. Grammar/mechanics }\end{array}$ & $\begin{array}{l}\text { - The document is clear and } \\
\text { concise. }\end{array}$ \\
\hline
\end{tabular}

Table 3. Written Communication Portion of Final Report Scoring Rubric 
"Focus" refers to the organization of the document; "Coherence" emphasizes the details of written communication (e.g., sentence structure, grammar and spelling). The scoring rubric was discussed with the student teams during the semester. In other words, the students were aware of how they would be evaluated.

IV. Results

\section{A. Reliability}

A total score for each report was determined by summing the resultant scores across the rubric categories. The maximum possible total score was 15 . Two trained raters each scored approximately half of the submitted reports. For reliability purposes, the raters scored four common reports. The raters had $100 \%$ agreement for the total scores on all four reports. On two of the reports, the raters had $100 \%$ agreement within all categories.

\section{B. Analysis}

As was discussed earlier, the design scoring rubric is comprised of five analytic factors: Audience, Purpose, Development, Focus, and Coherence. Total score was defined to be the sum across each of the analytic levels. Table 4 displays the descriptive statistics by gender composition for each of these five factors and for total score.

As this table suggests, female dominated teams on average had the highest total score and had the highest score with respect to each of the analytic factors. Mixed gender teams had the lowest total score and the lowest score with respect to each of the analytic factors.

Six one-factor Analyses of Variances (ANOVA) were completed to determine whether the mean with respect to the different gender compositions differed with respect to total score and with respect to each of the five factors. A significant difference was found for the total score $(\mathrm{p}=.04, \underline{\mathrm{F}}=2.85)$ and the audience factor $(\mathrm{p}=.01, \underline{\mathrm{F}}=3.92)$. Tukey's method for multiple comparisons was used to identify which gender compositions contributed to these findings. With respect to total scores, female dominated teams had a significantly higher mean score than did equally mixed teams. With respect to the audience factor, female dominated and male dominated teams had a significantly higher mean score than did equally mixed teams.

In order to better understand the results presented above, each team was categorized as to whether the student members were taking Design EPICS I or Design EPICS II. Table 5 displays the descriptive statistics by course. As this table suggests, teams' average scores increased with respect to each of the analytic factors and with respect to the total score from Design EPICS I to Design EPICS II. Six one tailed t-tests were completed to determine whether the average score with respect to each of the analytic factors and total score was greater for Design EPICS II than for Design EPICS I. Significant differences were found for audience $(\mathrm{p}=0.00, \underline{\mathrm{t}}=6.04)$ and total score $(\mathrm{p}=0.02, \underline{\mathrm{t}}=2.06)$.

"Proceedings of the 2002 American Society for Engineering Education Annual Conference \& Exposition Copyright (C) 2002, American Society for Engineering Education” 


\begin{tabular}{|l|c|c|c|c|c|}
\hline & & All Male & $\begin{array}{c}\text { Male } \\
\text { Dominated }\end{array}$ & $\begin{array}{c}\text { Female } \\
\text { Dominated }\end{array}$ & $\begin{array}{c}\text { Equally } \\
\text { Mixed }\end{array}$ \\
\hline Audience & $\overline{\mathrm{x}}$ & 1.57 & $1.72^{*}$ & $2.09^{*}$ & $.88^{*}$ \\
\hline & $\mathrm{s}$ & .69 & .86 & .70 & .99 \\
\hline Purpose & $\overline{\mathrm{x}}$ & 1.95 & 1.69 & 2.09 & 1.50 \\
\hline & $\mathrm{s}$ & .78 & .66 & .83 & .53 \\
\hline Development & $\overline{\mathrm{x}}$ & 1.81 & 1.49 & 1.82 & 1.38 \\
\hline & $\mathrm{s}$ & .70 & .64 & .60 & .52 \\
\hline Focus & $\overline{\mathrm{x}}$ & 1.86 & 1.74 & 2.00 & 1.50 \\
\hline & $\mathrm{s}$ & .75 & .79 & .63 & .53 \\
\hline Coherence & $\overline{\mathrm{x}}$ & 1.68 & 1.56 & 1.82 & 1.50 \\
\hline & $\mathrm{s}$ & .63 & .64 & .75 & .53 \\
\hline Total Score & $\overline{\mathrm{x}}$ & 8.87 & 8.21 & $9.82^{*}$ & $6.75 *$ \\
\hline & $\mathrm{s}$ & 2.65 & 2.40 & 2.56 & 1.49 \\
\hline
\end{tabular}

Table 4. Descriptive Statistics for Each Analytic Factor

\begin{tabular}{|l|c|c|c|}
\hline & & Design EPICS I & Design EPICS II \\
\hline Audience & $\overline{\mathrm{x}}$ & $1.34^{*}$ & $2.23^{*}$ \\
\hline & $\mathrm{s}$ & 0.76 & 0.62 \\
\hline Purpose & $\overline{\mathrm{x}}$ & 1.78 & 1.90 \\
\hline & $\mathrm{s}$ & 0.70 & 0.79 \\
\hline Development & $\overline{\mathrm{x}}$ & 1.61 & 1.71 \\
\hline & $\mathrm{s}$ & 0.63 & 0.74 \\
\hline Focus & $\overline{\mathrm{x}}$ & 1.78 & 1.84 \\
\hline & $\mathrm{s}$ & 0.72 & 0.78 \\
\hline Coherence & $\overline{\mathrm{x}}$ & 1.63 & 1.65 \\
\hline & $\mathrm{s}$ & 0.65 & 0.61 \\
\hline Total Score & $\overline{\mathrm{x}}$ & $8.14^{*}$ & $9.32^{*}$ \\
\hline & $\mathrm{s}$ & 2.35 & 2.75 \\
\hline
\end{tabular}

Table 5. Descriptive Statistics for Each Course

Differences were then examined within Design EPICS I and Design EPICS II with respect to gender composition. Since these subcategories resulted in small sample sizes for some groupings, this analysis is restricted to descriptive statistics and is shown in Table 6. Mixed gender teams in Design EPICS I consistently performed lower than all other team compositions with respect to each of the analytic factors. All male teams in Design EPICS I on average had the highest total score and outperformed all other team compositions with respect to purpose and development. Male dominated teams in Design EPICS I had the highest average scores with respect to focus and coherence while female dominated teams had the highest average score with respect to audience. Female

"Proceedings of the 2002 American Society for Engineering Education Annual Conference \& Exposition Copyright (C) 2002, American Society for Engineering Education” 
dominated teams outperformed all male and male dominated teams in Design EPICS II with respect to audience, purpose, focus, coherence and total score.

Another observation that can be made from this table is that all male teams and female dominated teams displayed a consistent increase with respect to all analytic factors and total score when comparing average performances in Design EPICS I to Design EPICS II. The increase for all male teams, however, was less than that of female teams as can be witnessed through the difference between total scores (All Male increase $=1.65$, Female Dominate increase $=2.97$ ). Another interesting observation is that male dominated teams displayed a decrease in total score between Design EPICS I and Design EPICS II. Male dominated teams did, however, have a higher average score with respect to audience than did all male teams. On all other analytic factors, male dominated teams displayed a decrease between Design EPICS I and Design EPICS II. No comparisons can be made with respect to mixed teams, since there were no mixed teams in Design EPICS II.

\begin{tabular}{|l|c|c|c|c|c|c|c|c|}
\hline & & \multicolumn{9}{|c|}{ EPICS I } & \multicolumn{3}{c|}{ EPICS II } \\
\hline & & $\begin{array}{c}\text { All } \\
\text { Male }\end{array}$ & $\begin{array}{c}\text { Male } \\
\text { Dominated }\end{array}$ & $\begin{array}{c}\text { Female } \\
\text { Dominated }\end{array}$ & Mixed & $\begin{array}{c}\text { All } \\
\text { Male }\end{array}$ & $\begin{array}{c}\text { Male } \\
\text { Dominated }\end{array}$ & $\begin{array}{c}\text { Female } \\
\text { Dominated }\end{array}$ \\
\hline Audience & $\overline{\mathrm{X}}$ & 1.43 & 1.35 & 1.60 & 0.88 & 2.00 & 2.25 & 2.50 \\
\hline & $\mathrm{s}$ & 0.69 & 0.78 & 0.55 & 0.99 & 0.50 & 0.68 & 0.55 \\
\hline Purpose & $\overline{\mathrm{x}}$ & 1.86 & 1.78 & 1.80 & 1.50 & 2.22 & 1.56 & 2.33 \\
\hline & $\mathrm{s}$ & 0.80 & 0.60 & 0.84 & 0.53 & 0.67 & 0.73 & 0.82 \\
\hline Development & $\overline{\mathrm{x}}$ & 1.75 & 1.52 & 1.60 & 1.38 & 2.00 & 1.44 & 2.00 \\
\hline & $\mathrm{s}$ & 0.70 & 0.59 & 0.55 & 0.52 & 0.71 & 0.73 & 0.63 \\
\hline Focus & $\overline{\mathrm{x}}$ & 1.82 & 1.87 & 1.60 & 1.50 & 2.00 & 1.56 & 2.33 \\
\hline & $\mathrm{s}$ & 0.77 & 0.76 & 0.55 & 0.54 & 0.71 & 0.81 & 0.52 \\
\hline Coherence & $\overline{\mathrm{x}}$ & 1.61 & 1.70 & 1.60 & 1.50 & 1.89 & 1.38 & 2.00 \\
\hline & $\mathrm{s}$ & 0.63 & 0.70 & 0.89 & 0.54 & 0.60 & 0.50 & 0.63 \\
\hline Total Score & $\overline{\mathrm{x}}$ & 8.46 & 8.22 & 8.20 & 6.75 & 10.11 & 8.19 & 11.17 \\
\hline & $\mathrm{s}$ & 2.60 & 2.28 & 2.05 & 1.49 & 2.52 & 2.64 & 2.23 \\
\hline
\end{tabular}

Table 6. Descriptive Statistics by Gender Composition within Course

\section{Conclusions}

The results presented above should be interpreted with caution. First, the Colorado School of Mines specializes in training students in science and engineering. When students enter CSM, they have already made the decision to enter a science or engineering career. Therefore, the students at CSM may be different from other first and second year students who are still exploring potential careers.

Another concern that should be considered is the limited number of female dominated and mixed gender teams. Unfortunately, women are a minority in the field of engineering and comprise only a small number of engineering students. At CSM, females comprise approximately $25 \%$ of the student population. This resulted in a limited number of female dominated $(n=11)$ and mixed gender teams $(n=8)$, making the identification of significant differences difficult. Given these cautionary statements, the results of this study are still interesting.

"Proceedings of the 2002 American Society for Engineering Education Annual Conference \& Exposition Copyright (C) 2002, American Society for Engineering Education” 
An original premise of this investigation was that males and females bring different skills to the team activity and that the combination of these skills would result in a higher level of performance. In the current study, this does not appear to be the case. Mixed gender teams displayed the lowest level of performance across all team compositions. All of the mixed gender teams in this study were in Design EPICS I. Possibly, cooperating in mixed gender teams requires a maturity level that is greater than that of the typical first year student. If this is the case, then the results reported here could change as students mature. The appropriateness of this assertion is left for future research.

Another interpretation of the above finding is that students may need assistance in learning to function effectively in mixed gender teams. Traditionally, engineering has been a male dominated field. Therefore, the ability to interact between genders has not been a skill that is required for success. As more and more females enter the field, mixed gender teams are likely to become more common. If future research confirms that students experience difficulties in mixed gender teams, then engineering programs will need to provide their graduates with the skills that are necessary to overcome these difficulties.

Another observation that was made with respect to the team compositions in the current investigation is that across courses, female dominated teams outperformed the other team compositions. This finding appears to be primarily accounted for by female dominated teams' performances in Design EPICS II. Although all male teams and male dominated teams had outperformed female dominated teams with respect to total score in Design EPICS I, female dominated teams had outperformed both of these team compositions with respect to Design EPICS II. Female dominated teams further displayed the greatest increase in average total score between Design EPICS I and Design EPICS II.

Prior literature ${ }^{3}$ has suggested that women may use the first year of college to correct academic deficiencies. After these deficiencies have been corrected, women are likely to be better equipped to display their engineering knowledge. The correction of academic deficiencies during the first year of college would partially explain why female dominated teams' performances increased at a greater rate than did all male teams between the first and second year courses. Additionally, women who are in their first year of engineering may lack the self-confidence that is necessary to excel in their engineering courses. After they have successfully completed their first year of college, these same women may both recognize their abilities and be better able to display their abilities. Research has also indicated that women often excel in teams that are primarily female $^{16}$. This same finding may be at work in the current investigation. As was discussed, female dominate teams outperformed mixed gender teams in Design EPICS I.

Another interesting observation in the current investigation is that female dominated teams performed particularly well with respect to the audience factor both across courses and within courses. In fact, with respect to audience, both male dominated teams and female dominated teams scored significantly higher than did mixed gender teams. In the second course, male dominated teams performed better with respect to this factor than did

"Proceedings of the 2002 American Society for Engineering Education Annual Conference \& Exposition Copyright (C) 2002, American Society for Engineering Education” 
all male teams. Possibly, the inclusion of a female in the male dominated teams resulted in the teams improved performance with respect to this factor. As was suggested above, females may lack confidence in their first year of engineering and this may limit their initial contributions to the team effort. This would explain why male dominated teams did not outperform all male teams with respect to audience factor in the first course. Female team members may not yet have had the confidence that was necessary to fully participate in the team process.

A final observation that was made in the current study was the lack of improvement with respect to total score that was witnessed with respect to male dominated teams. Male dominated teams average total score was lower in Design EPICS II than in Design EPICS I. This result was not witnessed with respect to any other group composition. Why did male dominated teams' performances decline with further instruction? Was this an unusual occurrence with respect to the current group of students or is this a more generalized result? Responding to these questions is left to future research.

\section{Bibliography}

1. Tate, W. F., "Race-ethnicity, SES, gender, and language proficiency trends in mathematics achievement: an update", Journal for Research in Mathematics Education, Vol. 28, No. 6, 1997, 652679.

2. Tierney, W., "The parameter of affirmative action: Equity and excellence in the academy", Review of Educational Research, Vol. 67, No. 2, 1997, 165-196.

3. Moskal, B., "Looking to the Future: Women in Science and Engineering", Proceedings of Frontiers in Education Conference, Kansas City, Missouri, October, 2000.

4. Fennema, E., "What Affirmative Action has Contributed to Educational Research", Educational Researcher, Vol. 27, No. 9, 1998, 5-7.

5. Greene, M., "Moral and Political Perspectives: The Tensions of Choice", Educational Researcher, Vol. 27, No. 9, 1998, 18-20.

6. Johnson, E. S., "College women's performance in math-science curriculum: A case study", College and University, Vol. 68, No. 2, 1993, 74-78.

7. Astin, A., Four critical years: Effects of college beliefs, attitudes and knowledge, San Francisco: Jossey-Bass, 1993.

8. Terenzini, P., Pascarella, E. \& Blimling, G., "Students' out-of class experience and their influence on learning and cognitive development: A literature review", Journal of College Student development, Vol. 37, No. 2, 1996, 149-163.

9. Moskal, B., Knecht, R. \& Lasich, D., "Engineering Design: The Effect of Gender on Leadership", Paper presented at the annual meeting of the American Educational Research Association, Seattle, Washington, April, 2001.

10. Laeser-MacDonell, M., Moskal, B., Knecht, R. \& Lasich, D., "The Engineering Process: Examining Male and Female Contributions", Paper appears in the Proceedings of the Frontiers in Education Conference, Reno, Nevada, Oct., 2001.

11. Moskal, B., Knecht, R. \& Pavelich, M. (2001). "The Design Report Rubric: Assessing the Impact of Program Design on the Learning Process". Journal for the Art of Teaching: Assessment of Learning, 8 (1), 18-33.

12. Knecht, R., Moskal, B. \& Pavelich, "The Design Report Rubric: Measuring and Tracking Growth Through Success", Paper in the Proceedings of the annual meeting American Society for Engineering Education, St. Louis, Missouri, June, 2000.

"Proceedings of the 2002 American Society for Engineering Education Annual Conference \& Exposition Copyright (C) 2002, American Society for Engineering Education” 
13. Brookhart, S., The Art and Science of Classroom Assessment: The Missing Part of Pedagogy, ASHEERIC Higher Education Report (Vol. 27, No.1). Washington, DC: The George Washington University, Graduate School of Education and Human Development, 1999.

14. Moskal, B., "Scoring Rubrics: What, When and How?", Practical Assessment, Research \& Evaluation, Vol. 7, No. 3., 2000 [Available online: http://ericae.net/pare/getvn.asp?v=7\&n=3].

15. Larson, C. \& Lafesto, F., "Teamwork: What Must Go Right or What Can Go Wrong". London: Sage Publishers, 1989.

16. Metzler, S. C., Kraemer, D. R. \& Grace, H. (1998). "Plugged In: An Interactive Program Designed to Advance the Scientific, Mathematics and Computer Literacy of Girls" [CD-ROM]. Abstract from: QuickTime File. Lifetime of Science, Engineering, and Mathematics. Program Number: 9555724.

\section{BARBARA M. MOSKAL}

Barbara Moskal is the Associate Director of the Center for Engineering Education and an Assistant Professor in the Mathematics and Computer Science Department at the Colorado School of Mines. Dr. Moskal is currently involved in a number of research investigations concerning the attraction, retention and advancement of women and minority students.

\section{ROBERT KNECHT}

Bob Knecht is currently the Director of Design EPICS at CSM. He spent 22 years in industry, providing technical and management assistance on minerals, energy and waste projects and supervising research, construction and start-up activities for several extraction processes. Based on his industrial experiences, he has developed curricula at CSM that incorporates industrial projects in the educational process.

\section{DEBRA K. LASICH}

Debra Lasich is the Executive Director of the Women in Science and Engineering (WISEM) program at the Colorado School of Mines. In this role, she has a strong impact on female undergraduate and graduate students and female faculty members. She is currently involved in a number of research efforts that concern the attraction, retention and advancement of female students. 